\title{
Effect of Innovative Food Processing Technologies on the Physicochemical and Nutritional Properties and Quality of Non-Dairy Plant-Based Beverages
}

\author{
Paulo E. S. Munekata ${ }^{1}$, Rubén Domínguez ${ }^{1}$, Sravanthi Budaraju ${ }^{2}$, Elena Roselló-Soto ${ }^{3}$, \\ Francisco J. Barba $^{3}{ }^{(1)}$, Kumar Mallikarjunan ${ }^{2}$, Shahin Roohinejad ${ }^{2,4}\left(\mathbb{C}\right.$ and José M. Lorenzo ${ }^{1, *(\mathbb{D})}$ \\ 1 Centro Tecnológico de la Carne de Galicia, rúa Galicia n 4, Parque Tecnológico de Galicia, San Cibrao das \\ Viñas, 32900 Ourense, Spain; paulosichetti@ceteca.net (P.E.S.M.); rubendominguez@ceteca.net (R.D.) \\ 2 Department of Food Science and Nutrition, University of Minnesota, St. Paul, MN 55108, USA; \\ budar006@umn.edu (S.B.); kumarpm@umn.edu (K.M.); falcon.roh@gmail.com (S.R.) \\ 3 Nutrition and Food Science Area, Preventive Medicine and Public Health, Food Science, Toxicology and \\ Forensic Medicine Department, Faculty of Pharmacy, Universitat de València, Avda. Vicent Andrés Estellés, \\ s/n 46100 Burjassot, València, Spain; eroso2@alumni.uv.es (E.R.-S.); francisco.barba@uv.es (F.J.B.) \\ 4 Burn and Wound Healing Research Center, Division of Food and Nutrition, Shiraz University of Medical \\ Sciences, 71348-14336 Shiraz, Iran \\ * Correspondence: jmlorenzo@ceteca.net; Tel.: +34-988-548-277
}

Received: 6 February 2020; Accepted: 29 February 2020; Published: 4 March 2020

\begin{abstract}
Increase in allergenicity towards cow's milk, lactose intolerance, the prevalence of hypercholesterolemia, and flexitarian choice of food consumption have increased the market for cow's milk alternatives. Non-dairy plant-based beverages are useful alternatives because of the presence of bioactive components with health-promoting properties, which attract health-conscious consumers. However, the reduced nutritional value and sensory acceptability of the plant-based beverages (such as flavor, taste, and solubility) compared to cow's milk pose a big threat to its place in the market. Thermal treatments are commonly used to ensure the quality of plant-based beverages during storage. However, the application of high temperatures can promote the degradation of thermolabile compounds and some detrimental reactions, thus reducing protein digestibility and amino acid availability of non-dairy plant-based beverages substitutes. New and advanced food processing technologies, such as high-pressure processing, high-pressure homogenization, pulsed electric fields, and ultrasound, are being researched for addressing the issues related to shelf life increase, emulsion stability, preservation of nutritional content and sensorial acceptability of the final product. However, the literature available on the application of non-thermal processing technologies on the physicochemical and nutritional properties of plant-based beverages is scarce. Concerted research efforts are required in the coming years in the functional plant-based beverages sector to prepare newer, tailor-made products which are palatable as well as nutritionally adequate.
\end{abstract}

Keywords: plant-based beverage; thermal treatments; non-thermal processing technologies; sensorial properties

\section{Introduction}

Over the last two decades, the consumption of non-dairy plant-based beverages, traditionally referred as "vegetable milks", coming from legumes (soybeans), cereals (rice and oats) or nuts (almonds and hazelnuts), has increased considerably [1] due to health and environmental concerns, lactose intolerance, and flexitarian choice of food consumption, despite their taste [2]. According to Markets and Markets [1], the estimated growth of plant-based beverage alternatives is $15 \%$ by 2018 , reaching a 
value of $\$ 14$ billion. Comparatively, the market value of non-dairy plant-based beverages is expected to achieve around $5 \%$ of the market of milk and dairy products in the next 6 years [3,4]. Plant-based beverage alternatives are used not only as "milks", but they are also extensively utilized in recipes as ingredients.

Typically, all the plant-based beverages are fluids that result from the process of maceration, grinding, and filtration, which consists of extracting food substances with water (accounting for about $90 \%$ of the final product). The traditional plant-based "milk" term is confusing from a nutritional point of view. Although the nutritional value of plant-based "milks" cannot be compared with cow's milk, some of these non-dairy plant based beverages present great interest as a source of proteins, such as that observed for quinoa and soymilk (Table 1). Unlike cow's milk, plant-based beverages contain no lactose or cholesterol, and they are usually sold with added calcium and vitamins, especially vitamin $B_{12}$. The most common sources for plant-based beverages include cereal-(oat, rice, corn, spelt, rye, quinoa, oats, spelt, kamut), legume-(soy, peanut, lupin, cowpea), nut-(almond, coconut, hazelnut, pistachio, walnut), seed-(sesame, flax, sunflower, pumpkin, hemp), and pseudocereal-based (quinoa, teff, amaranth). Recent findings have drawn attention to the utilization of cereals, oilseeds, and nuts for new applications due to their functional properties (due to the large content of bioactive compounds present in these foods), which reveal the physical attributes of food components and their interactions [5].

Plant-based beverages are usually subjected to ultra-high-temperature (UHT) treatment before being packaged to ensure food quality and safety during storage. However, the conventional high-temperature processing can promote the degradation of thermolabile compounds and some detrimental reactions, thus affecting the physicochemical properties and improving the off-flavor formation, for instance [6]. In order to reduce these drawbacks, alternative processing technologies such as high hydrostatic pressure, high-pressure homogenization, ultrasound, and pulsed electric fields have been proposed. The scientific evaluation of these innovative processing technologies revealed promising results to improve the shelf life, preserve the nutritional properties and reduce the loss of bioactive compounds of the plant-based beverages [5]. Some of the most relevant thermal and non-thermal innovative technologies which could be used for plant-based milk preservation as well as their potential applications are shown in Figure 1.

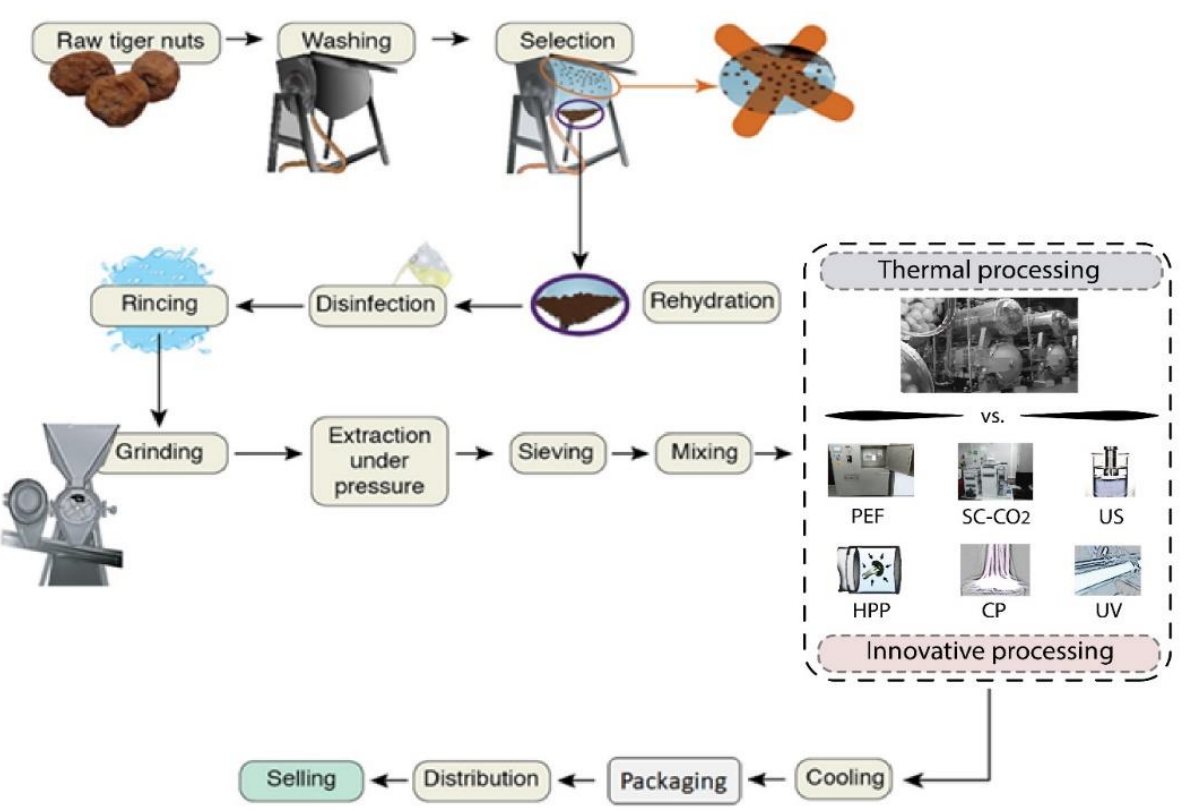

Figure 1. Innovative technologies with the potential to be used in the preservation of plant-based beverages (adapted from Roselló-Soto et al. [7]). 
However, based on our knowledge, in comparison with dairy products, little scientific literature is available on the application of these technologies for plant-based beverages. Thus, this review outlines the intervention of various innovative processing technologies and their effect on the physicochemical and nutritional properties of plant-based beverages. The current limitations and suggestions for further studies regarding innovative processing technologies are also highlighted.

\section{The Nutritional and Bioactive Composition of the Most Commonly Consumed Plant-Based Beverages}

Plant-based beverages are quite variable in their composition compared to cow's milk. The nutrients and amount of sugar in plant-based milk differ considerably according to the production process and product formulation. The nutritional composition of the most commonly consumed plant-based beverages and their characteristics are listed in Table 1. Among the different type of plant-based beverages, rice and sesame milks have the highest total carbohydrates $(>15 \%)$ and calorie amount ( $>130$ calories), while quinoa and soy milks contain the highest protein level $(>4 \%)$.

Plant-based beverages are rich in bioactive compounds, but the particular bioactive compound differs according to the type of beverage. The bioactive compounds found in this type of products include: $\beta$-glucan, which is associated with improved blood glucose and insulin resistance [8]; phytosterols, which can improve the cardiovascular status and reduce the risk associated with related diseases [9]; isoflavones, which can reduce the risk related to development of cardiovascular diseases, cancer, and osteoporosis [10]; lignans, having the ability to reduce the blood cholesterol level [11]; and omega- 3 fatty acids, which are involved in the adequate development and protection against the development of cardiovascular diseases, for instance [12]. Conversely, some antinutritional compounds can be also found in plant-based beverages. For instance, sesame and oat contain oxalate and phytates $[8,11]$ that form insoluble complexes with minerals, carbohydrates and lipids during digestion and reduced availability of these nutrients [13]. Another important compound is amandin, an allergenic protein found in almonds [14].

Table 1. Nutritional composition of most commonly consumed plant-based beverages per 8 oz cup along with their functional and antinutritional components.

\begin{tabular}{|c|c|c|c|c|c|c|c|}
\hline $\begin{array}{l}\text { Type of } \\
\text { Milk }\end{array}$ & $\begin{array}{l}\text { Calories } \\
\text { (kcal) }\end{array}$ & Protein $(\mathrm{g})$ & Lipids (g) & $\begin{array}{c}\text { Total } \\
\text { Carbohydrates } \\
\text { (g) }\end{array}$ & $\begin{array}{l}\text { Functional } \\
\text { Compounds }\end{array}$ & Characteristics & Reference \\
\hline $\begin{array}{l}\text { Cow's } \\
\text { milk }\end{array}$ & 61 & 3.15 & 3.25 & 4.8 & - & - & [15] \\
\hline Oat & 80 & 2.5 & 4 & - & $\beta$-Glucan & $\begin{array}{c}\text { Antinutritional } \\
\text { compounds such as } \\
\text { phytates }\end{array}$ & {$[8,16,17]$} \\
\hline Rice & 130 & 1 & 2 & 27 & $\begin{array}{c}\text { Phytosterols } \\
\text { ( } \beta \text {-sitosterol and } \\
\gamma \text {-oryzanol })\end{array}$ & $\begin{array}{l}\text { Poor emulsion stability } \\
\text { due to high starch } \\
\text { content }\end{array}$ & {$[9,18-20]$} \\
\hline Quinoa & 104 & 4.5 & 6 & 9 & $\begin{array}{l}\text { Manganese, } \\
\text { Phosphorous }\end{array}$ & - & [9] \\
\hline Soy & 80 & 7 & 4 & 4 & $\begin{array}{l}\text { Isoflavones, } \\
\text { Phytosterols }\end{array}$ & $\begin{array}{l}\text { Beany flavor due to the } \\
\text { action of lipoxygenase } \\
\text { on unsaturated fatty } \\
\text { acids }\end{array}$ & [10] \\
\hline Almond & 40 & 1 & 3 & 2 & $\begin{array}{l}\alpha \text {-Tocopherol, } \\
\text { Arabinose }\end{array}$ & $\begin{array}{l}\text { Presence of allergenic } \\
\text { protein amandin }\end{array}$ & {$[5,14]$} \\
\hline Coconut & 80 & $<1$ & 5 & 7 & $\begin{array}{l}\text { Lauric acid, } \\
\text { Vitamin E }\end{array}$ & - & [21] \\
\hline Hazelnut & 124 & 1.4 & 6 & 14 & Catechin & - & [22] \\
\hline Sesame & 140 & 1.5 & 6 & 16.5 & $\begin{array}{l}\text { Lignans (sesamin, } \\
\text { sesamolin, } \\
\text { sesaminol) }\end{array}$ & $\begin{array}{l}\text { Antinutritional factors } \\
\text { such as oxalate }\end{array}$ & [11] \\
\hline Hemp & 70 & 2 & 6 & 1 & $\begin{array}{l}\text { Omega 3-fatty } \\
\text { acids }\end{array}$ & - & [5] \\
\hline
\end{tabular}


Moreover, from a nutritional point of view and taking into account the new trends found in some countries reducing the consumption of cow's milk while increasing the consumption of non-dairy plant-based beverages, it should be emphasized that the nutritional value of plant-based beverages differ by far from that of cow's milk [23]. For instance, it should be borne in mind that replacing cow's milk with non-dairy plant-based beverages leads to a reduced intake of protein, calcium, certain vitamins (i.e., vitamin D) and minerals as well as a higher intake of added salt (Table 1 and Figure 2). In addition, from a physiological point of view, the intake of cow's milk has nothing to do with plant-based beverages, due to the different nutritional composition. Therefore, taking into account the actual calcium, magnesium, and vitamin D deficits, such substitution should be done with caution and it is necessary to compensate for nutrient deficiencies in a balanced way using other food sources, in case it is necessary to replace cow's milk, either for reasons of intolerance, allergies or others not related (e.g., religious, ethical, social).

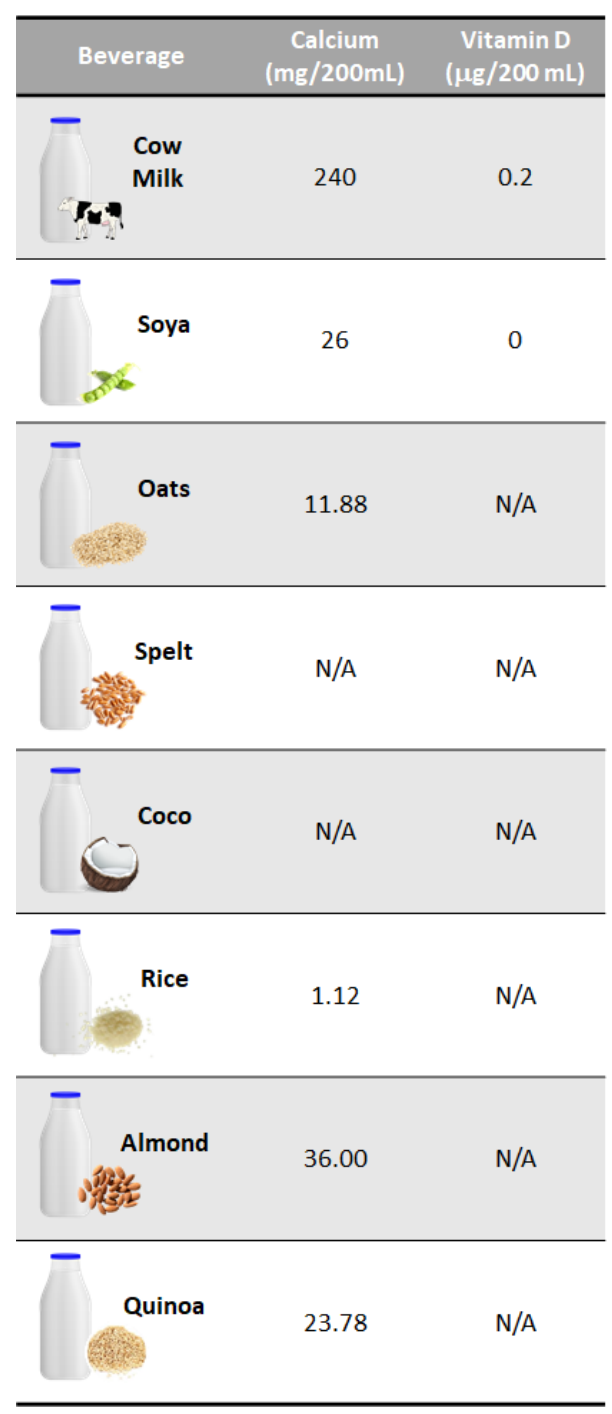

Figure 2. Calcium and vitamin D contents of non-dairy plant-based beverages compared to cow's milk (values obtained from Sousa et al. [23]). 


\section{Application of Various Innovative Technologies for the Processing of Plant-Based Beverages}

\subsection{High-Hydrostatic-Pressure Processing}

The history of using high hydrostatic pressure (HHP) goes back to the 19th century when Soxhlet applied pressure to convert starch into glucose. HHP involves the use of pressure in the range of $100-800 \mathrm{MPa}$, with or without the application of heat [24,25]. In practical applications, the combined intensity of both thermal and pressure effects can cause various physical, chemical, and biological changes in foods. HHP can be conducted in either batch or semicontinuous process depending on the type of food. The use of HHP alters the characteristics of milks, particularly proteins, and leads to desired texture, sensory attributes, and nutritional value [26].

The effect of HHP can also contribute to reducing the allergenic character of some plant-based beverages. For instance, the impact of HHP on allergenic almond proteins was evaluated by Dhakal et al. [14]. In this study, the stability of the main almond allergenic protein amandin in the raw almond milk was evaluated under HHP treatment (450 and $600 \mathrm{MPa}$ for 0, 30, 60, 180, 300, and $600 \mathrm{~s}$ at $\left.30^{\circ} \mathrm{C}\right)$ and traditional thermal processing $\left(0,30,180\right.$, and $300 \mathrm{~s}$ at 72,85 , and $\left.99^{\circ} \mathrm{C}\right)$. The results showed that amandin levels were affected by all HHP treatments. The reactivity with antilinear epitopes of monoclonal antibodies was reduced by half while the signal from specific anticonformational monoclonal antibodies was no longer detected in HHP-treated samples. One of the explanations indicated by authors for these results was the aggregation of amandin, which can potentially reduce the immunological response in amandin-sensitive people. It is worth noting that similar results for conventional thermal processing were reported for treatments at increased temperature and time of $300 \mathrm{~s}$ at 85 and $99^{\circ} \mathrm{C}$. Additionally, the authors highlighted the necessity for further studies regarding the inactivation of allergenic proteins in almond milk, since HHP alone may not inactivate all allergenic factors. Combining HHP with other strategies such as changing $\mathrm{pH}$, adding chemical additives, and increasing temperature could improve the inactivation of allergenic almond proteins, as stated by the authors.

The use of HHP also displayed an important role in the development of soymilk enriched with calcium [27]. In this experiment, a Doehlert design was used to optimize the HHP processing conditions (500-700 MPa at $73-95^{\circ} \mathrm{C}$ ) and level of calcium $(5,10$, and $15 \mathrm{mmol} / \mathrm{L}$ ) in order to enhance protein solubility and inactivation of trypsin inhibitors and lipoxygenase. The authors indicated that, in the optimum conditions $\left(614 \mathrm{MPa}, 85.5^{\circ} \mathrm{C}\right.$, and $\left.8.53 \mathrm{mmol} \mathrm{Ca} / \mathrm{L}\right)$, both enzymes were completely inhibited and more than $70 \%$ of proteins were solubilized in the bulk of soymilk.

\subsection{High-Pressure Homogenization}

The high-pressure homogenization (HPH) or ultra-high-pressure homogenization (UHPH) is an alternative food processing method which can be used to improve the stability of plant-based milk emulsions and their physicochemical properties with minimum effect on the nutritional properties [22]. This technique uses high pressures ranging from 200 to $600 \mathrm{MPa}$ and temperatures between 30 and $85{ }^{\circ} \mathrm{C}$ and can improve the stability of plant-based beverages by reducing the particle size of emulsions and producing more uniform size particles [28]. Apart from reducing colloidal particles, simultaneous destruction of microorganisms can be achieved using UHPH [29]. In a study performed by Briviba et al. [30], a threefold increase in mean particle size was reported, while no significant reduction in vitamin $B_{1}$ and $B_{2}$ contents after $\mathrm{UHPH}$ treatment $\left(350 \mathrm{MPa}\right.$ at $\left.85^{\circ} \mathrm{C}\right)$ was observed. Moreover, the application of UHPH treatment resulted in reducing the almond protein antigens response by $99.8 \%$.

The impact of UHPH (200-300 MPa) on the physicochemical properties (particle size and color) of soybean-based milks was compared with the results obtained from UHT-treated samples [29]. A significant reduction of particle size after UHPH was observed, but the aggregate formation was found only at $300 \mathrm{MPa}$. Although a partial protein denaturation after $200 \mathrm{MPa}$ was observed, UHPH at $300 \mathrm{MPa}$ led to similar protein denaturation to that found after UHT treatments. Moreover, UHPH 
soybean-based milks were more stable than UHT processed samples (particle aggregation during storage). Processing (UHPH and UHT), as well as storage time, had a significant influence on color parameters (CIE-Lab) wherein the lowest values were found in the samples treated by UHPH at $300 \mathrm{MPa}\left(79.68,-2.66\right.$, and 16.01 for $\mathrm{L}, \mathrm{a}^{*}$, and $\mathrm{b}^{*}$, respectively) in relation to UHPH at $200 \mathrm{MPa}(82.24$, -2.00 , and 16.57 for $\mathrm{L}, \mathrm{a}^{*}$, and $\mathrm{b}^{*}$, respectively) and UHT $\left(84.31,-0.28\right.$, and 18.37 for $\mathrm{L}$, $\mathrm{a}^{*}$, and $\mathrm{b}^{*}$, respectively).

In another study, the impact of UHPH $\left(200-300 \mathrm{MPa} / 40-50^{\circ} \mathrm{C}\right)$ on the properties of soybean-based milks was evaluated and compared with conventional thermal treatments (UHT and autoclaved) [31]. The authors evaluated the characteristics of soy-yogurts obtained from heat-treated soybean-based milks. The study showed an increased onset of gelation as well as decreased aggregation rate and gel network density on soybean-based milks treated by UHPH compared to heat treatments, which resulted in improved physiochemical properties (i.e., firmness).

Ferragut et al. [32] investigated the effect of UHPH treatment $\left(200 \mathrm{MPa}\right.$ at $55^{\circ} \mathrm{C}$ and $300 \mathrm{MPa}$ at $75^{\circ} \mathrm{C}$ ) on the chemical composition, digestibility and essential amino acid content of an almond milk. The results of this study indicated non-significant differences in the chemical composition of almond milks subjected to both UHPH treatments and conventional thermal processing (pasteurization and ultra-high-temperature). It is worth mentioning that UHPH treatments did not affect the essential amino acid content, particularly lysine (a limiting amino acid in almond milks). However, the impact in a potential bioactive component can be greater than in chemical composition of plant-based beverages. In this sense, Toro-Funes et al. [33] evaluated the effect of UHPH on the stability of phytosterols, tocopherols, and polyamines in almond milk. UHPH (200 and $300 \mathrm{MPa}$ at 55, 65, and $\left.75^{\circ} \mathrm{C}\right)$ treatment affected the content of phytosterols, tocopherols, and polyamines. Increasing pressure and temperature reduced the total tocopherol content (sum of $\alpha-, \beta-$, and $\gamma$-tocopherol) from 50.63 to 3.15 and $4.14 \mathrm{mg} / \mathrm{L}$, in raw almond milk treated at $200 \mathrm{MPa}, 75^{\circ} \mathrm{C}$ and $300 \mathrm{MPa}, 75^{\circ} \mathrm{C}$, respectively. However, an inverse effect was reported for total phytosterols content, which increased from $22.08 \mathrm{mg} / \mathrm{L}$ in raw almond milk to 27.24 and $29.54 \mathrm{mg} / \mathrm{L}$ after UHPH treatment at $200 \mathrm{MPa}, 75^{\circ} \mathrm{C}$ and $300 \mathrm{MPa}, 75^{\circ} \mathrm{C}$, respectively. According to the authors, this outcome could be derived from the mechanical forces (such as shear force, turbulence, and cavitation) reducing the fat globule size and facilitating the release of phytosterols in the bulk of the beverage.

Another important consideration is the impact of $\mathrm{HPH}$ on the volatile composition of plant-based beverages. The experiment carried out by Poliseli-Scopel et al. [34] evaluated the effect of UHPH (200 MPa, 55 or $75^{\circ} \mathrm{C}$ and $300 \mathrm{MPa}, 80^{\circ} \mathrm{C}$ ) on the volatile compounds profile of soybean-based milks and compared the results to those treated by the conventional pasteurization $\left(90^{\circ} \mathrm{C}, 30 \mathrm{~s}\right)$ and UHT $\left(142^{\circ} \mathrm{C}, 6 \mathrm{~s}\right)$. Apart from the type of treatment, hexanal was found to be the predominant compound [34]. Moreover, significant changes regarding the volatile compounds profile were observed after UHT and UHPH treatments wherein the highest modifications were observed after UHT treatments compared to untreated samples. Interestingly, Pérez-González et al. [35] used the headspace-solid-phase microextraction (HS-SPME) technique to characterize and detect changes in the volatile profile of almond milks arising from the technological treatments applied in the production of almond milk. The authors concluded that the predominant volatile compounds were benzaldehyde and hexanal, followed by ketone and alcohol. Interestingly, compounds such as furans and pyrazines (derived from thermal treatments) were detected to a lesser extent.

Likewise, some authors [36,37] compared the physicochemical and sensorial properties of UHPH-treated $\left(200-300 \mathrm{MPa}, 55-75^{\circ} \mathrm{C}\right)$, pasteurized $\left(90^{\circ} \mathrm{C}, 30 \mathrm{~s}\right)$, and UHT $\left(142{ }^{\circ} \mathrm{C}, 6 \mathrm{~s}\right)$ soymilk beverages. The application of UHPH at $200 \mathrm{MPa}$ and $55^{\circ} \mathrm{C}$ resulted in improved sensorial characteristics, color, and colloidal stability compared to samples treated with conventional thermal procedures [36,37]. Moreover, hydroperoxide index values were reduced and higher trypsin inhibitor activity in UHPH samples was observed compared to samples treated with conventional pasteurization and UHT techniques. A similar outcome was observed in a posteriori study carried out by Poliseli-Scopel et al. [37]. In the study, the impact of UHPH $\left(300 \mathrm{MPa}, 80^{\circ} \mathrm{C}\right)$ and UHT $\left(142{ }^{\circ} \mathrm{C}, 6 \mathrm{~s}\right)$ on soymilk beverage 
during storage were evaluated. The microbial growth was inhibited throughout storage time by both treatments, the hydroperoxide index was reduced during storage for both treatments, and sensory evaluation revealed slight differences between treatments that did not influence the panelists to differentiate treatments.

Toro-Funes et al. [38] evaluated the impact of UHPH $\left(200-300 \mathrm{MPa}, 55-75^{\circ} \mathrm{C}\right)$ on the isoflavone profile, protein digestibility, and lysine availability immediately after the treatments and during subsequent refrigerated storage $\left(4^{\circ} \mathrm{C}\right)$ for 21 days. The results were compared to those obtained after conventional thermal pasteurization. The authors did not observe a significant modification in isoflavone profile after conventional pasteurization or UHPH processing compared to untreated samples. However, the conversion of isoflavone forms to aglycones during storage was reported, especially after conventional thermal pasteurization. Moreover, the percentage of blocked lysine was lower after UHPH, while no significant changes were found in protein digestibility during storage, independently of the applied treatment.

In a similar study, the same research group also compared the isoflavones and protein digestibility and lysine availability of UHPH ( $300 \mathrm{MPa}$ and $75^{\circ} \mathrm{C}$ of inlet temperature) and UHT-sterilized $\left(142{ }^{\circ} \mathrm{C}\right.$, $6 \mathrm{~s})$ soybean-based beverages, immediately after the processing and during 4 months of storage at $20{ }^{\circ} \mathrm{C}[39$ ]. The isoflavones' extractability was improved after UHT $(\approx 38 \%)$ treatment compared to UHPH-treated samples $(\approx 15 \%)$ immediately after processing. However, no significant differences were found in the total content of isoflavones at the end of the storage. Moreover, a faster interconversion of isoflavones into $\beta$-glucosides after UHT treatment was observed compared to UHPH-processed samples. A similar evolution of protein digestibility in both UHPH- and UHT-treated soybean-based beverages was found, being slightly higher in the initial UHT (88.4\%) than in UHPH-treated samples $(83.3 \%)$. Great differences were not observed in the percentage of blocked lysine among samples after treatments or in their evolution throughout storage [39]. Although important scientific advances were made in the characterization and storage stability of plant-based beverages processed by UHPH technology, further studies are necessary to optimize processing conditions to inactivate antinutritional factors and endogenous enzymes associated with quality decay.

\subsection{Other Innovative Processing Technologies}

The application of other advanced food treatments, processing parameters and the main effect on plant-based beverages are shown in detail in Table 2. Ultrasonication is another promising technology for homogenization of cow's milk, but its application in plant-based beverages is poorly explored [40]. Iswarin and Permadi [41] investigated the effect of ultrasonic waves with different combinations of power levels ( 2.5 to $7.0 \mathrm{~W}$ ) and exposure times ( 5 to $25 \mathrm{~min}$ ) on droplet diameter of coconut-based milks. The diameter of the droplet size was reported to be reduced by increasing ultrasound's power and time of processing. However, power levels were found to significantly affect particle size more than the duration of exposure. 
Table 2. Application of innovative processing technologies and their effect on various plant-based beverages.

\begin{tabular}{|c|c|c|c|c|}
\hline Novel Method & Plant-Based Milks & Treatment Conditions & Inference & Reference \\
\hline \multirow{2}{*}{$\begin{array}{l}\text { High hydrostatic pressure } \\
\text { (HHP) }\end{array}$} & Almond milk & $\begin{array}{l}\mathrm{HHP}(450 \text { and } 600 \mathrm{MPa} \text { for } 0 \text {, } \\
30,60,180,300 \text {, and } 600 \mathrm{~s} \text { at } \\
\left.30^{\circ} \mathrm{C}\right) \text { and traditional thermal } \\
\text { processing }(0,30,180 \text {, and } 300 \\
\left.\text { s at } 72,85, \text { and } 99^{\circ} \mathrm{C}\right) .\end{array}$ & $\begin{array}{l}\text { Induced the aggregation and } \\
\text { coagulation of almond } \\
\text { proteins; higher aggregation } \\
\text { than conventional heat } \\
\text { treatment }\left(72 \text { and } 85^{\circ} \mathrm{C}\right)\end{array}$ & [26] \\
\hline & $\begin{array}{l}\text { Soymilk enriched } \\
\text { with calcium }\end{array}$ & $\begin{array}{c}\mathrm{HHP}(500-700 \mathrm{MPa} \text { at } \\
\left.73-95^{\circ} \mathrm{C}\right) \text { and traditional } \\
\text { thermal processing }(80,85,90, \\
\left.95^{\circ} \mathrm{C} \text { at } 0.1 \mathrm{MPa}\right)\end{array}$ & $\begin{array}{l}\text { Inhibited the activity of } \\
\text { trypsin inhibitors and } \\
\text { lipoxygenase; improved } \\
\text { protein solubility, viscosity, } \\
\text { and stability (up to } 5 \text { days) }\end{array}$ & [27] \\
\hline \multirow{7}{*}{$\begin{array}{c}\text { High-pressure } \\
(\mathrm{HPH}) / \text { Ultra-high-pressure } \\
\text { homogenization }(\mathrm{UHPH})\end{array}$} & \multirow{3}{*}{ Almond milk } & $\mathrm{UHPH}\left(350 \mathrm{MPa}\right.$ at $\left.85^{\circ} \mathrm{C}\right)$. & $\begin{array}{c}\text { No significant reduction in } \\
\text { vitamins } B_{1} \text { and } B_{2} \text {. Reduction } \\
\text { in anti-protein antigens by } \\
99.8 \% \text { was achieved }\end{array}$ & [30] \\
\hline & & $\begin{array}{l}\mathrm{UHPH}(200 \text { and } 300 \mathrm{MPa} \text { at } \\
\left.55^{\circ} \mathrm{C}, 65^{\circ} \mathrm{C} \text { and } 75^{\circ} \mathrm{C}\right)\end{array}$ & $\begin{array}{l}\text { Increased total phytosterols } \\
\text { content; reduced the total } \\
\text { tocopherol content }\end{array}$ & [38] \\
\hline & & $\begin{array}{c}\mathrm{HPH}(150,300,450 \text {, and } \\
\left.600 \mathrm{MPa}, 30^{\circ} \mathrm{C} \text {, up to } 600 \mathrm{~s}\right) \\
\text { and traditional thermal } \\
\text { processing (up to } 300 \mathrm{~s} \text { at } 72 \text {, } \\
\quad 85 \text {, and } 99^{\circ} \mathrm{C} \text { ) }\end{array}$ & $\begin{array}{l}\text { Reduced protein solubility (up } \\
\text { to } 70 \% \text { ) and amandin } \\
\text { immunoreactivity }\end{array}$ & [14] \\
\hline & Soy yogurt & $\begin{array}{c}\mathrm{HPH}(200-300 \mathrm{MPa} \text { at } \\
\left.40-50^{\circ} \mathrm{C}\right)\end{array}$ & $\begin{array}{c}\text { Improved physiochemical } \\
\text { properties (e.g., firmness) of } \\
\text { the yogurts (milk treated by } \\
\text { HPH) }\end{array}$ & [31] \\
\hline & \multirow[t]{3}{*}{ Soymilk } & $\begin{array}{l}\text { UHPH }(200-300 \mathrm{MPa}, \\
\left.55-75^{\circ} \mathrm{C}\right)\end{array}$ & $\begin{array}{l}\text { No effect on isoflavone profile } \\
\text { after processing and protein } \\
\text { digestibility during storage }\end{array}$ & {$[33,38]$} \\
\hline & & $\begin{array}{l}\text { UHPH-treated soymilk } \\
\left(200 \mathrm{MPa}, 55-75^{\circ} \mathrm{C}\right) \text { and } \\
\text { thermal pasteurization }\left(90^{\circ} \mathrm{C} \text {, }\right. \\
30 \mathrm{~s})\end{array}$ & $\begin{array}{l}\text { Improved color and colloidal } \\
\text { stability; reduced } \\
\text { hydroperoxide index values } \\
\text { and trypsin activity }\end{array}$ & {$[36,37]$} \\
\hline & & $\begin{array}{c}\mathrm{UHPH}\left(300 \mathrm{MPa} \text { and } 75^{\circ} \mathrm{C} \text { of }\right. \\
\text { inlet temperature) and UHT } \\
\text { sterilization }\left(142^{\circ} \mathrm{C}, 6 \mathrm{~s}\right)\end{array}$ & $\begin{array}{l}\text { No significant difference in } \\
\text { isoflavones extractability, } \\
\text { protein digestibility }\end{array}$ & [39] \\
\hline Ultrasonication (US) & Coconut milk & $\begin{array}{l}\text { US power levels ( } 2.5 \text { to } 7.0 \mathrm{~W} \text { ) } \\
\text { and treatment time (5 to } 25 \\
\text { min) }\end{array}$ & $\begin{array}{l}\text { Droplet diameter was reduced } \\
\text { by increasing US power and } \\
\text { time }\end{array}$ & [41] \\
\hline \multirow[b]{2}{*}{ Pulsed Electric Field (PEF) } & Tiger nut milk & $\begin{array}{l}\text { PEF pulse time }(100 \mu \mathrm{s} \text { and } \\
475 \mu \mathrm{s}) \text { and electric field } \\
\text { intensity }(20 \mathrm{kV} / \mathrm{cm} \text { and } \\
35 \mathrm{kV} / \mathrm{cm})\end{array}$ & $\begin{array}{l}\text { No change in fat content } \\
(3.04 \%) \text { throughout the storage } \\
\text { period; reduced formation of } \\
\text { lipid oxidation products }\end{array}$ & [42] \\
\hline & Soymilk & $\begin{array}{c}\text { PEF with electric field } \\
\text { intensities }(18,20 \text {, and } \\
22 \mathrm{kV} / \mathrm{cm}) \text {, number of pulses } \\
(25,50,75 \text {, and } 100), \\
\text { capacitance from the discharge } \\
\text { capacitor of } 0.33 \mathrm{~L} \text { and pulse } \\
\text { frequency of } 0.5 \mathrm{~Hz} \text { at } 26^{\circ} \mathrm{C}\end{array}$ & $\begin{array}{l}\text { Increased viscosity }(22 \mathrm{kV} / \mathrm{cm} \\
\text { with } 100 \text { pulses })\end{array}$ & [43] \\
\hline
\end{tabular}

The pulsed electric fields (PEF) is an interesting non-thermal technology used to inactivate microorganisms in different food products with minimum effect on flavor, color, or nutritional compounds [44]. Food is placed between two electrodes and subjected to very short pulses (for 
milliseconds/even in microseconds) at high voltages (1 to $80 \mathrm{kV} / \mathrm{cm})$. Depending on the requirements (such as microbial inactivation, the disintegration of sludge, and electro-permeabilization), food products are subjected to various ranges of voltages [45]. PEF processing involves very short but strong pulses, thus shortening total processing time (TPT) with high efficiency. Common TPT is measured in minutes since pauses between pulses can be longer than pulse time itself [46].

Regarding the impact of such technology on plant-based beverages, Cortés et al. [42] investigated the effect of PEF processing on the quality attributes of "horchata" (tiger nut milk), a typical plant-based beverage from Spain [47]. The study evaluated the impact of treatment time (100-475 microseconds) and electric field intensity $(20-35 \mathrm{kV} / \mathrm{cm})$ during 5 days at $5{ }^{\circ} \mathrm{C}$, while the temperatures during the treatment did not exceed $35^{\circ} \mathrm{C}$. According to the authors, the $\mathrm{pH}$ decrease during storage was ameliorated by PEF treatment that was even more influenced by treatment time. Samples subjected to longer PEF treatments, in the same electric field intensity, had higher $\mathrm{pH}$ values than samples subjected to short treatment times. The inhibition of peroxidase activity was another effect obtained from this experiment. Although the regeneration of such enzyme was observed in all PEF treatments, the enzymatic activity of peroxidase at the end of storage did not achieve the same level observed for untreated samples [42].

In the study conducted by Xiang [43], the rheological and color properties of the soybean-based milks were evaluated after PEF treatment wherein the effect of electric field intensity $(18,20$, and $22 \mathrm{kV} / \mathrm{cm})$ and number of pulses $(25,50,75$, and 100$)$ at $26^{\circ} \mathrm{C}$ were evaluated. The rheological properties of soybean-based milks were affected by PEF treatment. The apparent viscosity increased from 6.62 to $7.46\left(10^{-3} \mathrm{~Pa} \cdot \mathrm{s}\right)$ by increasing the electric field intensity from 18 to $22 \mathrm{kV} / \mathrm{cm}$ and pulses from 0 to 100 . The authors argued that this effect could be related to the formation of transient networks from the denatured molecules.

\section{Effect of Innovative Processing Methods on Off-Flavor, Stability, and Shelf Life of Plant-Based Beverages}

\subsection{Removal and Prevention of Off-Flavor Generation}

Among the non-dairy plant-based beverages, soy products are gaining importance due to their high-quality protein and positive effects on health. However, in order to increase the acceptability, several efforts have been made to reduce its displeasing, beany, or unpleasant flavor [48]. Unsaturated fatty acids and lipoxygenases are involved in the release of off-flavors in most of the plant-based beverages, which include soymilk [49]. In this sense, important strategies such as inactivating enzymes, removal of off-flavors by deodorization, and masking off-flavor by addition of artificial or natural flavorings are the most commonly used methods [5].

For instance, Zhang et al. [50] explored the effect of processing conditions and soy variety on selected volatile compounds of soymilk, particularly those derived from oxidative reactions. This study revealed that hot grinding $\left(80.5^{\circ} \mathrm{C}\right)$ combined with a two-phase UHT processing (vacuum evaporation at $50 \mathrm{kPa}$ ) was the most effective treatment to remove volatile compounds (such as hexanal, 2-pentylfuran, and (E,E)-2,4-nonadienal) from soymilk in comparison to low and ambient temperature grinding. The authors also argued that applying vacuum after thermal treatment (UHT process) of soymilk was considered as the main factor to achieve the low level of selected volatile compounds. Similarly, UHPH can effectively reduce the "beany" flavor in soymilk [34]. The authors observed that beany and grass sensory scores of UHPH-treated soymilks at $200 \mathrm{MPa} / 75^{\circ} \mathrm{C}$ were lower than obtained by another processing condition (pasteurized and UHPH at $200 \mathrm{MPa} / 55^{\circ} \mathrm{C}$ ). Although many studies have shown promising approaches to eliminate "beany" and off-odor flavor from plant-based milks [51-53], more efforts are necessary to improve the actual frame and characterize the impact of new technologies and approaches. 


\subsection{Improving Product Stability}

Product stability is an important parameter of plant-based milks. In general, during storage, the colloidal particles sediment or settle, making the plant-based milks unstable. Monitoring particle size can be of great value in order to understand the stability of plant-based beverages. The main consequence of particle aggregation and consequent precipitation is the impact on sensory properties of plant-based beverages, which can display lower scores regarding taste, consistency, and aroma [54]. Innovative food processing technologies display great potential to improve the storage stability of plant-based beverages. For instance, the use of UHPH technology (200 MPa at both 55 and $75{ }^{\circ} \mathrm{C}$ ) prevented the sedimentation of suspended particles during refrigerated storage [34]. It is important to highlight that pasteurization improved the stabilization of suspended particles right after processing and during storage, but UHPH produced a more stable product. A similar outcome was reported for the processing of soymilk enriched with calcium treated with HHP [27]. In this case, the addition of calcium increased the sedimentation of particles after 5 days of storage, particularly for samples prepared with $15 \mathrm{mmol} \mathrm{Ca} / \mathrm{L}$ and treated with conventional thermal processing $\left(80\right.$ and $90{ }^{\circ} \mathrm{C}$ at $0.1 \mathrm{MPa}$ ). Conversely, the HHP samples (550 MPa at $83.7^{\circ} \mathrm{C}$ and $650 \mathrm{MPa}$ at $77.4^{\circ} \mathrm{C}$ ) displayed lower sedimentation after the same period in comparison to samples treated with conventional thermal processing and untreated soymilk. According to the authors, enhancing the solubilization of proteins and eventual formation of a protein network could explain the improved stability during storage.

Likewise, Bernat et al. [22] evaluated the impact of HPH and heat treatment (alone and combined treatments) on the particle size of almond and hazelnut milk. Increasing pressure on HPH treatment (up to $172 \mathrm{MPa}$ ) was associated with a lower volume mean diameter in comparison to untreated beverages than thermally treated beverages $\left(85^{\circ} \mathrm{C}\right.$ for $30 \mathrm{~min}$ and at $121^{\circ} \mathrm{C}$ for $15 \mathrm{~min}$ ) for both beverages. The combination of HPH $\left(172 \mathrm{MPa}\right.$ at $85^{\circ} \mathrm{C}$ for $30 \mathrm{~min}$ or $121^{\circ} \mathrm{C}$ for $\left.15 \mathrm{~min}\right)$ and thermal treatment partially reduced the volume mean diameter of a suspended particle of both beverages. Additionally, increasing temperature was associated with a higher volume mean diameter in the combined treatment, which according to authors supports the use of HPH followed by low thermal processing to improve the stability of almond and hazelnut beverages. It is worth mentioning that a study carried out by Cruz et al. [29] reported an interesting effect of HPH on the volume mean diameter of a suspended particle of soymilk. In this study, $200 \mathrm{MPa}$ treatment reduced the volume mean diameter in comparison to untreated and UHT samples ( $0.13 \mathrm{vs} .0 .55$ and $0.47 \mu \mathrm{m}$, respectively) while the $300 \mathrm{MPa}$ treatment induced a drastic increase in volume mean diameter $(4.36 \mu \mathrm{m})$.

\subsection{Shelf Life Improvement}

Plant-based beverages are a rich source of nutrients for many microorganisms, which may affect product quality and safety during storage. The application of thermal treatments not only extends the shelf life of plant-based beverages but was also proven to improve taste and general acceptability [55]. One of the possible approaches to reduce the impact of heat treatment on the quality of plant-based beverages is combining effective time and temperature combinations. Several combinations have been tested so far: pasteurization at temperatures below $100^{\circ} \mathrm{C}$, sterilization at $121{ }^{\circ} \mathrm{C}$ for up to $20 \mathrm{~min}$, and ultra-high temperature between 135 and $150{ }^{\circ} \mathrm{C}$ [5]. However, aseptic packaging is still necessary to preserve innocuity. Further storage at low temperature is required for pasteurized beverages, while sterilized products can be stored at room temperature $[5,56]$.

The impact of innovative technologies on the shelf life of plant-based beverages is shown in Table 3. Several studies support the use of UHPH as a promising technology to improve the shelf life of plant-based beverages. The main advantage is the partial or integral inactivation of microbial load, which can increase the shelf life of plant-based beverages. For instance, UHPH (200 and $300 \mathrm{MPa}$, $40{ }^{\circ} \mathrm{C}$ ) reduced the microbial load in tiger nut milk, particularly Enterobacteriaceae, Lactobacillus, molds, and yeasts [57]. The partial destruction of psychrotrophic and aerobic mesophilic bacteria was also reported by authors. However, no effect on mesophilic spores was observed on UHPH-treated tiger 
nut milk. Similar results for UHPH treatment were reported by other authors regarding the reduction of initial microbial load of freshly prepared plant-based beverages [28,29,34,36,37].

Similarly, Smith et al. [58] observed that HHP treatment reduced total bacterial count in a pressure-dependent manner wherein higher pressure yielded higher inhibition effect up to 4 days. After this period and up to 28 days of storage, total bacteria counts were similar among treatments. Differently, psychrotrophic bacteria were inactivated by HHP treatment at $75{ }^{\circ} \mathrm{C}$ with a pressure higher than $500 \mathrm{MPa}$, regardless of dwell time (1 or $5 \mathrm{~min})$. Likewise, Poliseli-Scopel et al. [34] evaluated the effect of temperature $\left(55\right.$ and $\left.75^{\circ} \mathrm{C}\right)$ during UHPH treatment $(200 \mathrm{MPa})$ on the evolution of total bacteria and spores of soymilk. After 28 days of refrigerated storage, the soymilk treated at $75{ }^{\circ} \mathrm{C}$ displayed similar microbial load as observed after UHPH treatment (day 1) for both total bacteria and spores. A mild inhibition effect was observed for soymilk treated at $55^{\circ} \mathrm{C}$.

Table 3. Effect of innovative processing technologies on shelf life of various plant-based beverages.

\begin{tabular}{|c|c|c|c|c|}
\hline Novel Method & Plant-Based Milks & $\begin{array}{l}\text { Treatment } \\
\text { Conditions }\end{array}$ & Antimicrobial Effect & Reference \\
\hline \multirow{6}{*}{$\begin{array}{l}\text { Ultrahigh pressure } \\
\text { homogenization }\end{array}$} & Tiger nut milk & $\begin{array}{c}200 \text { and } 300 \mathrm{MPa} \text { at } \\
40^{\circ} \mathrm{C}\end{array}$ & $\begin{array}{c}\text { Total inhibition of } \\
\text { Enterobacteriaceae, } \\
\text { Lactobacillus, molds, and } \\
\text { yeasts growth; partial } \\
\text { inhibition of psychrotrophs } \\
\text { and aerobic mesophiles } \\
\text { growth, no effect on } \\
\text { mesophilic spores }\end{array}$ & [57] \\
\hline & \multirow{4}{*}{ Soymilk } & $\begin{array}{c}200 \text { and } 300 \mathrm{MPa} \text { at } \\
40^{\circ} \mathrm{C}\end{array}$ & $\begin{array}{l}\text { Drastic reduction on total } \\
\text { count, spores, and } \\
\text { enterobacteria counts by } \\
\text { both treatments }\end{array}$ & [29] \\
\hline & & $\begin{array}{l}200 \text { and } 300 \mathrm{MPa} \text {, } \\
55-75^{\circ} \mathrm{C}\end{array}$ & $\begin{array}{l}\text { Complete inhibition of total } \\
\text { bacteria, total spores and } \\
\text { Bacillus cereus growth by } \\
200 \mathrm{MPa} \text { at } 75^{\circ} \mathrm{C} \text { and } \\
300 \mathrm{MPa} \text { at } 55-75^{\circ} \mathrm{C}\end{array}$ & {$[36]$} \\
\hline & & $\begin{array}{c}200 \mathrm{MPa}, 55 \text { and } \\
75^{\circ} \mathrm{C}\end{array}$ & $\begin{array}{l}200 \mathrm{MPa} \text { at } 75^{\circ} \mathrm{C} \text { inhibited } \\
\text { the growth of total bacteria } \\
\text { and total spores during } 28 \\
\text { days of refrigerated storage }\end{array}$ & {$[34]$} \\
\hline & & $300 \mathrm{MPa}$ at $80^{\circ} \mathrm{C}$ & $\begin{array}{l}\text { Complete inhibition of } \\
\text { mesophilic and thermophilic } \\
\text { bacteria }\end{array}$ & {$[37]$} \\
\hline & Almond milk & $\begin{array}{l}200 \text { and } 300 \mathrm{MPa} \text {, } \\
55-75^{\circ} \mathrm{C}\end{array}$ & $\begin{array}{l}\text { Destruction of total bacteria, } \\
\text { total spores, and Bacillus } \\
\text { cereus growth by } 200 \mathrm{MPa} \text { at } \\
75^{\circ} \mathrm{C} \text { and } 300 \mathrm{MPa} \text { at } \\
55-75^{\circ} \mathrm{C}\end{array}$ & {$[28]$} \\
\hline $\begin{array}{l}\text { High-pressure } \\
\text { processing }\end{array}$ & Soymilk & $\begin{array}{l}400-600 \mathrm{MPa}, 25 \\
\text { and } 75^{\circ} \mathrm{C}, 1 \text { and } \\
5 \mathrm{~min}\end{array}$ & $\begin{array}{c}\text { Inhibition of total bacterial } \\
\text { growth up to } 4 \text { days; } \\
400-600 \mathrm{MPa} \text { at } 75{ }^{\circ} \mathrm{C} \\
\text { caused total inhibition of } \\
\text { aerobic bacteria for } 28 \text { days }\end{array}$ & [58] \\
\hline $\begin{array}{l}\text { Pulsed electric } \\
\text { fields }\end{array}$ & Soymilk & $\begin{array}{c}20-40 \mathrm{kV} / \mathrm{cm} \\
0-547 \mu \mathrm{s}\end{array}$ & $\begin{array}{c}\text { Inactivation of Escherichia } \\
\text { coli and Staphylococcus aureus } \\
\text { was proportional to } \\
\text { increasing strength and } \\
\text { treatment time }\end{array}$ & [59] \\
\hline $\begin{array}{l}\text { High-intensity } \\
\text { pulsed electric } \\
\text { fields }\end{array}$ & Horchata & $\begin{array}{c}2.5-3 \mathrm{MV} / \mathrm{m}, \\
50-300 \mu \mathrm{s}, 5-16^{\circ} \mathrm{C}\end{array}$ & $\begin{array}{c}\text { Treatments increase the lag } \\
\text { phase of Enterobacter } \\
\text { aerogenes inoculated to } \\
\text { horchata }\end{array}$ & {$[60]$} \\
\hline $\begin{array}{l}\text { Radio-frequency } \\
\text { flash heating }\end{array}$ & Soymilk & $3.5-28 \mathrm{MHz}$ & $\begin{array}{l}4 \text { log reduction in Bacillus } \\
\text { subtilis spores by } 28 \mathrm{MHz}\end{array}$ & {$[61]$} \\
\hline
\end{tabular}


It is worth mentioning that other technologies can contribute to improving the safety of plant-based beverages such as PEF. For instance, Escherichia coli and Staphylococcus aureus loads in soymilk were reduced in a strength- and processing-time-dependent manner. The highest reduction (5.7 and 3.5 $\log _{10}$ reductions in Escherichia coli and Staphylococcus aureus, respectively) was obtained by treating inoculated soymilk with $40 \mathrm{kV}$ for $547 \mu$ s [59]. Selma et al. [60] explored the impact of high-intensity PEF (2.5-3 MV/m, 50-300 $\left.\mu \mathrm{s}, 5-16{ }^{\circ} \mathrm{C}\right)$ on horchata inoculated with Enterobacter aerogenes. The lag phase of treated horchata was improved in comparison to untreated samples. Particularly, for samples incubated at $16^{\circ} \mathrm{C}$, the lag phase obtained from untreated samples was $4.6 \mathrm{~h}$, while in samples treated with high-intensity PEF, this lag phase was improved to 12.2-16.7 h. However, the authors obtained a maximum of $1.1 \mathrm{log}$ reduction of Enterobacter aerogenes in treated samples. Likewise, Uemura et al. [61] inactivated Bacillus subtilis spores by applying radio-frequency flash heating treatment (a technology that heats food by electromagnetic radiation) in soymilk. The study revealed that by treating soymilk with $28 \mathrm{MHz}$, a reduction of $4 \log$ in Bacillus subtilis spores was obtained. However, the feasibility of this technology, along with other non-thermal technologies such as pulsed light, to improve the shelf life of the plant-based beverages requires additional studies.

\section{Challenges and Recommendations for Future Studies}

Application of advanced food processing technologies like high pressure and PEF for the preservation of plant-based beverages presents numerous advantages over conventional heat treatment. However, the combination of innovative technologies with heating is still a major challenge for their successful consolidation in the plant-based beverage industry as processing technologies. In order to achieve this goal, more efforts are necessary to study the scale-up (since most of the technologies are currently at lab scale) and characterize the processing conditions at continuous regime with large flows, particularly for HPH technology.

Another relevant aspect that must be considered in further experiments is the effect of innovative technologies in the bioaccessibility of functional ingredients found or intentionally added in plant-based beverages for the development of new functional beverages. Scientific evidence indicated that phenolic compounds found in soymilk could be absorbed after the gastrointestinal digestion and exert antioxidant activity [62].

From this approach, the strategies for commercialization could be enhanced by viewing these products as a combination of benefits: primarily the individual relation to milk consumption (consumption of cholesterol- and/or lactose-free products, for instance) and the additional intention to health benefits (presence of bioactive compounds). This motivation mainly associated with young consumers, such as reported in the UK [63]. Therefore, both technological and consumer studies should consider targeting young consumers for the development of new products, the application of innovative technologies and characterization of this niche in the food market.

\section{Conclusions}

The plant-based beverages segment of food market has experienced enormous expansion prospective for the health food market and needs to be widely investigated through the development of advanced processing, technological interventions, and fortification techniques for developing nutritionally complete plant-based beverages with high overall acceptability. Plant-based beverages are associated with huge health and functional benefits, as discussed. Exploring advanced food processing technologies such as pulsed electric fields, high-pressure homogenization, and high-hydrostatic-pressure homogenization technologies can be helpful to tackle factors responsible for limiting the success in the processing such plant-based beverages on a larger scale. The effect of advanced technologies on plant-based beverages properties during both processing and storage require more studies in order to ensure that these technologies can prevent the loss of quality and promote the successful inactivation of antinutritional factors. Plant-based beverages will continue to be a major research area in the newer product development category of food science and technology. 
Author Contributions: Conceptualization, P.E.S.M., S.B., K.M. and S.R.; Writing-original draft preparation, P.E.S.M., S.B. and E.R.-S.; Writing-review and editing, R.D., F.J.B. and J.M.L. All authors have read and agreed to the published version of the manuscript.

Funding: This research received no external funding.

Acknowledgments: Author Sravanthi Budaraju would like to thank the University of Minnesota for her graduate assistantship. Paulo E. S. Munekata acknowledges postdoctoral fellowship support from Ministry of Economy and Competitiveness (MINECO, Spain) "Juan de la Cierva" program (FJCI-2016-29486). Thanks to GAIN (Axencia Galega de Innovación) for supporting this research (grant number IN607A2019/01). Moreover, Francisco J. Barba and Jose M. Lorenzo thank Generalitat Valenciana for the financial support (IDIFEDER/2018/046-Procesos innovadores de extracción y conservación: pulsos eléctricos y fluidos supercríticos) through European Union ERDF funds (European Regional Development Fund). In addition, this work was supported by the project GV/2018/040 "Implementación y optimización de procesos innovadores para la valorización de los subproductos obtenidos a partir del proceso de elaboración de la horchata" for emerging research groups from the Generalitat Valenciana.

Conflicts of Interest: The authors declare no conflict of interest.

\section{References}

1. Markets and Markets Dairy Alternative (Milk) Market by Type (Soy, Almond, Rice), Formulation (Plain, Flavored, Sweetened, Unsweetened), Channel (Supermarket, Health Store, Pharmacy, Convenience Store) \& Geography_Global Trends \& Forecast to 2018. Available online: https://www.marketsandmarkets.com/ Market-Reports/dairy-alternative-plant-milk-beverages-market-677.html (accessed on 3 March 2020).

2. Silva, A.R.A.; Silva, M.M.N.; Ribeiro, B.D. Health issues and technological aspects of plant-based alternative milk. Food Res. Int. 2020, 131, 108972. [CrossRef]

3. Research and Markets Global Dairy Products Market Report 2019, Forecast to 2025-Growing DEMAND for dairy Alternatives Hampering Growth. Available online: https://markets.businessinsider.com/news/stocks/ global-dairy-products-market-report-2019-forecast-to-2025-growing-demand-for-dairy-alternativeshampering-growth-1028592785 (accessed on 3 March 2020).

4. Research and Markets \$35+ Billion Dairy Alternatives Market E Consumption Report, 2020-2026; Research and Markeds: Dublin, Ireland, 2020.

5. Sethi, S.; Rahul, S.K.T.; Anurag, R.K. Plant-based milk alternatives an emerging segment of functional beverages: A review. J. Food Sci. Technol. 2016, 53, 3408-3423. [CrossRef]

6. Barba, F.J.; Carbonell-Capella, J.M.; Esteve, M.J.; Frígola, A. Automating a 96-well microtiter plate assay for quick analysis of chemically available lysine in foods. Food Anal. Methods 2013, 6, 1258-1264. [CrossRef]

7. Roselló-Soto, E.; Poojary, M.M.; Barba, F.J.; Koubaa, M.; Lorenzo, J.M.; Mañes, J.; Moltó, J.C. Thermal and non-thermal preservation techniques of tiger nuts' beverage "horchata de chufa". Implications for food safety, nutritional and quality properties. Food Res. Int. 2018, 105, 945-951. [CrossRef]

8. Welch, R.W. Oats in human nutrition and health. In The Oat Crop-Production and Utilization; Welch, R.W., Ed.; Springer: Dordrecht, The Netherlands, 1995; pp. 443-479.

9. Pineli, L.L.O.; Botelho, R.B.A.; Zandonadi, R.P.; Solorzano, J.L.; de Oliveira, G.T.; Reis, C.E.G.; Teixeira, D.S. Low glycemic index and increased protein content in a novel quinoa milk. LWT-Food Sci. Technol. 2015, 63, 1261-1267. [CrossRef]

10. Omoni, A.O.; Aluko, R.E. Soybean foods and their benefits: Potential mechanisms of action. Nutr. Rev. 2005, 63, 272-283. [CrossRef]

11. Namiki, M. Nutraceutical functions of sesame: A review. Crit. Rev. FoodScience Nutr. 2007, 47, 651-673. [CrossRef]

12. Shahidi, F.; Ambigaipalan, P. Omega-3 polyunsaturated fatty acids and their health benefits. Annu. Rev. Food Sci. Technol. 2018, 9, 345-381. [CrossRef]

13. Kumar, V.; Sinha, A.K.; Makkar, H.P.S.; Becker, K. Dietary roles of phytate and phytase in human nutrition: A review. Food Chem. 2010, 120, 945-959. [CrossRef]

14. Dhakal, S.; Liu, C.; Zhang, Y.; Roux, K.H.; Sathe, S.K.; Balasubramaniam, V.M. Effect of high pressure processing on the immunoreactivity of almond milk. Food Res. Int. 2014, 62, 215-222. [CrossRef]

15. USDA. USDA Nutrient Database for Standard Reference, Release; USDA: Washington, DC, USA, 2019.

16. Truswell, A.S. Cereal grains and coronary heart disease. Eur. J. Clin. Nutr. 2006, 56, 1-14. [CrossRef] [PubMed] 
17. Deswal, A.; Deora, N.S.; Mishra, H.N. Optimization of enzymatic production process of oat milk using response surface methodology. Food Bioprocess Technol. 2014, 7, 610-618. [CrossRef]

18. Biswas, S.; Sircar, D.; Mitra, A.; De, B. Phenolic constituents and antioxidant properties of some varieties of Indian rice. Nutr. Food Sci. 2013, 41, 123-135. [CrossRef]

19. Faccin, G.L.; Vieira, N.; Miotto, L.A.; Barreto, P.L.M.; Amante, E.R. Chemical, sensorial and rheological properties of a new organic rice bran beverage. Rice Sci. 2009, 16, 226-234. [CrossRef]

20. Mitchell, C.R.; Mitchell, P.R.; Nissenbaum, R. Nutritional Rice Milk Production. U.S. Patent 4744992, 1988.

21. Seow, C.C.; Gwee, C.N. Review coconut milk: Chemistry and technology. Int. J. Food Sci. Technol. 1997, 32, 189-201. [CrossRef]

22. Bernat, N.; Cháfer, M.; Rodríguez-García, J.; Chiralt, A.; González-Martínez, C. Effect of high pressure homogenisation and heat treatment on physical properties and stability of almond and hazelnut milks. LWT-Food Sci. Technol. 2015, 62, 488-496. [CrossRef]

23. Sousa, A.; Bolanz, K.A.K. Nutritional implications of an increasing consumption of non-dairy plant-based beverages instead of cow's milk in Switzerland. Adv. Dairy Res. 2017, 5. [CrossRef]

24. Soxhlet, F. Supposed conversion of starch into sugar by water at a high temperature. J. Chem. Soc. Abstr. 1881, 42, 554-557.

25. Balasubramaniam, V.M.; Martínez-Monteagudo, S.I.; Gupta, R. Principles and application of high pressure-based technologies in the food industry. Annu. Rev. Food Sci. Technol. 2015, 6, 435-462. [CrossRef]

26. Dhakal, S.; Giusti, M.M.; Balasubramaniam, V.M. Effect of high pressure processing on dispersive and aggregative properties of almond milk. J. Sci. Food Agric. 2016, 3821-3830. [CrossRef]

27. Manassero, C.A.; Vaudagna, S.R.; Sancho, A.M.; Añón, M.C.; Speroni, F. Combined high hydrostatic pressure and thermal treatments fully inactivate trypsin inhibitors and lipoxygenase and improve protein solubility and physical stability of calcium-added soymilk. Innov. Food Sci. Emerg. Technol. 2016, 35, 86-95. [CrossRef]

28. Valencia-Flores, D.C.; Hern, M.; Guamis, B.; Ferragut, V. Comparing the effects of ultra-high-pressure homogenization and conventional thermal treatments on the microbiological, physical, and chemical quality of almond beverages. J. Food Sci. 2013, 78, 199-205. [CrossRef]

29. Cruz, N.; Capellas, M.; Hernández, M.; Trujillo, A.J.; Guamis, B.; Ferragut, V. Ultra high pressure homogenization of soymilk: Microbiological, physicochemical and microstructural characteristics. Food Res. Int. 2007, 40, 725-732. [CrossRef]

30. Briviba, K.; Gräf, V.; Walz, E.; Guamis, B.; Butz, P. Ultra high pressure homogenization of almond milk: Physico-chemical and physiological effects. Food Chem. 2016, 192, 82-89. [CrossRef]

31. Cruz, N.; Capellas, M.; Jaramillo, D.P.; Trujillo, A.J.; Guamis, B.; Ferragut, V. Soymilk treated by ultra high-pressure homogenization: Acid coagulation properties and characteristics of a soy-yogurt product. Food Hydrocoll. 2009, 23, 490-496. [CrossRef]

32. Ferragut, V.; Hernandez-Herrero, M.; Veciana-Nogues, M.T.; Borras-Suarez, M.; Gonzalez-Linares, J.; Vidal-Carou, M.C.; Guamis, B. Ultra-high-pressure homogenization (UHPH) system for producing high-quality vegetable-based beverages: Physicochemical, microbiological, nutritional and toxicological characteristics. J. Sci. Food Agric. 2015, 95, 953-961. [CrossRef]

33. Toro-Funes, N.; Bosch-Fusté, J.; Veciana-Nogués, M.T.; Vidal-Carou, M.C. Effect of ultra high pressure homogenization treatment on the bioactive compounds of soya milk. Food Chem. 2014, 152, 597-602. [CrossRef]

34. Poliseli-Scopel, F.H.; Gallardo-Chacón, J.-J.; Juan, B.; Guamis, B.; Ferragut, V. Characterisation of volatile profile in soymilk treated by ultra high pressure homogenisation. Food Chem. 2013, 141, 2541-2548. [CrossRef]

35. Pérez-González, M.; Gallardo-Chacón, J.J.; Valencia-Flores, D.; Ferragut, V. Optimization of a Headspace SPME GC-MS methodology for the analysis of processed almond beverages. Food Anal. Methods 2015, 8, 612-623. [CrossRef]

36. Poliseli-Scopel, F.H.; Hernández-Herrero, M.; Guamis, B.; Ferragut, V. Comparison of ultra high pressure homogenization and conventional thermal treatments on the microbiological, physical and chemical quality of soymilk. LWT-Food Sci. Technol. 2012, 46, 42-48. [CrossRef]

37. Poliseli-Scopel, F.H.; Hernández-Herrero, M.; Guamis, B.; Ferragut, V. Sterilization and aseptic packaging of soymilk treated by ultra high pressure homogenization. In Innovative Food Science and Emerging Technologies; Elsevier Ltd.: Amsterdam, The Netherlands, 2014; Volume 22, pp. 81-88. 
38. Toro-Funes, N.; Bosch-Fusté, J.; Veciana-Nogués, M.T.; Vidal-Carou, M.C. Influence of ultra-high-pressure homogenization treatment on the phytosterols, tocopherols, and polyamines of almond beverage. J. Agric. Food Chem. 2014, 62, 9539-9543. [CrossRef]

39. Toro-Funes, N.; Bosch-Fusté, J.; Latorre-Moratalla, M.L.; Veciana-Nogués, M.T.; Vidal-Carou, M.C. Isoflavone profile and protein quality during storage of sterilised soymilk treated by ultra high pressure homogenisation. Food Chem. 2015, 167, 78-83. [CrossRef]

40. Jafari, S.M.; He, Y.; Bhandari, B. Production of sub-micron emulsions by ultrasound and microfluidization techniques. J. Food Eng. 2007, 82, 478-488. [CrossRef]

41. Iswarin, S.J.; Permadi, B. Coconut milk's fat breaking by means of ultrasound. Int. J. Basic Appl. Sci. 2012, 12, 1-5.

42. Cortés, C.; Esteve, M.J.; Frígola, A.; Torregrosa, F. Quality characteristics of horchata (a Spanish vegetable beverage) treated with pulsed electric fields during shelf-life. Food Chem. 2005, 91, 319-325. [CrossRef]

43. Xiang, B. Effects of pulsed electric fields on structural modification and rheological properties for selected food proteins. Ph.D. Thesis, Sainte-Anne-de-Bellevue, McGill University, Montreal, AB, Canada, 2008.

44. Barba, F.J.; Parniakov, O.; Pereira, S.A.; Wiktor, A.; Grimi, N.; Boussetta, N.; Saraiva, J.A.; Raso, J.; Martin-Belloso, O.; Witrowa-Rajchert, D.; et al. Current applications and new opportunities for the use of pulsed electric fields in food science and industry. Food Res. Int. 2015, 77, 773-798. [CrossRef]

45. Puértolas, E.; Koubaa, M.; Barba, F.J. An overview of the impact of electrotechnologies for the recovery of oil and high-value compounds from vegetable oil industry: Energy and economic cost implications. Food Res. Int. 2016, 80, 19-26. [CrossRef]

46. Koubaa, M.; Barba, F.J.; Kovačević, D.B.; Putnik, P.; Santos, M.D.; Queirós, R.P.; Moreira, S.A.; Inácio, R.S.; Fidalgo, L.G.; Saraiva, J.A. Pulsed Electric Field Processing of Fruit Juices. In Fruit Juices-Extraction, Composition, Quality and Analysis; Rajauria, G., Tiwari, B.K., Eds.; Academic Press: Cambridge, MA, USA, 2018; pp. 437-449. ISBN 9780128022306.

47. Gabrić, D.; Barba, F.; Roohinejad, S.; Gharibzahedi, S.M.T.; Radojčin, M.; Putnik, P.; Kovačević, D.B. Pulsed electric fields as an alternative to thermal processing for preservation of nutritive and physicochemical properties of beverages: A review. J. Food Process Eng. 2018, 41, e12638. [CrossRef]

48. Ma, L.; Li, B.; Han, F.; Yan, S.; Wang, L.; Sun, J. Evaluation of the chemical quality traits of soybean seeds, as related to sensory attributes of soymilk. Food Chem. 2015, 173, 694-701. [CrossRef]

49. Abagoshu, N.A.; Ibrahim, A.M.; Teka, T.A.; Mekonnen, T.B. Effect of soybean varieties and processing methods on nutritional and sensory properties of soymilk. J. Food Process. Preserv. 2017, 41, 1-9. [CrossRef]

50. Zhang, Y.; Guo, S.; Liu, Z.; Chang, S.K.C. Off-flavor related volatiles in soymilk as affected by soybean variety, grinding, and heat-processing methods. J. Agric. Food Chem. 2012, 60, 7457-7462. [CrossRef] [PubMed]

51. Blagden, T.; Gilliland, S.E. Reduction of levels of volatile components associated with the "Beany" flavor in soymilk by Lactobacilli and Streptococci. J. Food Sci. 2005, 70, M186-M189. [CrossRef]

52. Lv, Y.-C.; Song, H.-L.; Li, X.; Wu, L.; Guo, S.-T. Influence of blanching and grinding process with hot water on beany and non-beany flavor in soymilk. J. Food Sci. 2011, 76, S20-S25. [CrossRef] [PubMed]

53. Tripathi, M.K.; Mangaraj, S.; Kumar, M.; Sinha, L.K.; Giri, S.K.; Ali, N. Effect of processing condition on the quality and beany flavour of soymilk. Curr. Sci. 2015, 109, 1164-1171.

54. Gul, O.; Atalar, I.; Mortas, M.; Turker, F.; Fehmi, S. Application of TOPSIS methodology to determine optimum hazelnut cake concentration and high pressure homogenization condition for hazelnut milk production based on physicochemical, structural and sensory properties. J. Food Meas. Charact. 2018, 12, 2404-2415. [CrossRef]

55. Ukwuru, M.U.; Ogbodo, A.C. Effect of processing treatment on the quality of tigernut milk. Pakistan J. Nutr. 2011, 10, 95-100. [CrossRef]

56. Giri, S.K.; Mangaraj, S. Processing influences on composition and quality attributes of soymilk and its powder. Food Eng. Rev. 2012, 4, 149-164. [CrossRef]

57. Codina-Torrella, I.; Guamis, B.; Zamora, A.; Quevedo, J.M.; Trujillo, A.J. Microbiological stabilization of tiger nuts' milk beverage using ultra-high pressure homogenization. A preliminary study on microbial shelf-life extension. Food Microbiol. 2018, 69, 143-150. [CrossRef]

58. Smith, K.; Mendonca, A.; Jung, S. Impact of high-pressure processing on microbial shelf-life and protein stability of refrigerated soymilk. Food Microbiol. 2009, 26, 794-800. [CrossRef] 
59. Li, Y.-Q.; Tian, W.-L.; Mo, H.-Z.; Zhang, Y.-L.; Zhao, X.-Z. Effects of pulsed electric field processing on quality characteristics and microbial inactivation of soymilk. Food Bioprocess Technol. 2013, 6, 1907-1916. [CrossRef]

60. Selma, M.V.; Fernández, P.S.; Valero, M.; Salmerón, M.C. Control of Enterobacter aerogenes by high-intensity, pulsed electric fields in horchata, a Spanish low-acid vegetable beverage. Food Microbiol. 2003, 20, 105-110. [CrossRef]

61. Uemura, K.; Takahashi, C.; Kobayashi, I. Inactivation of Bacillus subtilis spores in soybean milk by radio-frequency flash heating. J. Food Eng. 2010, 100, 622-626. [CrossRef]

62. Guo, Y.; Ma, M.; Jiang, F.; Jiang, W.; Wang, H.; Du, S. kui Protein quality and antioxidant properties of soymilk derived from black soybean after in vitro simulated gastrointestinal digestion. Int. J. Food Sci. Technol. 2020, 55, 720-728. [CrossRef]

63. Mylan, J.; Morris, C.; Beech, E.; Geels, F.W. Rage against the regime: Niche-regime interactions in the societal embedding of plant-based milk. Environ. Innov. Soc. Transit. 2019, 31, 233-247. [CrossRef]

(C) 2020 by the authors. Licensee MDPI, Basel, Switzerland. This article is an open access article distributed under the terms and conditions of the Creative Commons Attribution (CC BY) license (http://creativecommons.org/licenses/by/4.0/). 